This is an electronic reprint of the original article. This reprint may differ from the original in pagination and typographic detail.

Author(s): Dodds, Mark

Title: How can sport sponsors comply with international corruption laws?

Year: $\quad 2018$

Version:

Please cite the original version:

Dodds, M. (2018). How can sport sponsors comply with international corruption laws?. In M. Dodds, K. Heisey, \& A. Ahonen (Eds.), Routledge Handbook of International Sport Business (pp. 224-229). Routledge. https://doi.org/10.4324/9781315709635-24

All material supplied via JYX is protected by copyright and other intellectual property rights, and duplication or sale of all or part of any of the repository collections is not permitted, except that material may be duplicated by you for your research use or educational purposes in electronic or print form. You must obtain permission for any other use. Electronic or print copies may not be offered, whether for sale or otherwise to anyone who is not an authorised user. 


\section{How can sport sponsors comply with international corruption laws}

Sport sponsorships can help a brand achieve commercial objectives such as direct sales, or brand awareness. International sporting events are being hosted by nations with a "bribery-friendly" business culture. The nexus between anticorruption laws and these "bribery-friendly" business cultures create a tension for sport sponsors. Violations of applicable anticorruption laws may lead to significant fines, criminal sanctions and negative publicity. It is imperative that sport sponsors know and comply with these laws.

This chapter aims to discuss bribery law, identify potential red flags that may indicate violations, and offer recommendations for legal compliance.

\section{Introduction}

Corruption is the "misuse of entrusted power for private gain" (Transparency International, 2016). It tends to be a "hidden crime" (Joutsen \& Keränen, Finland, 2009, p.1). Often there are no witnesses to the offense but this crime harms the public by compensating actors for non-work, encouraging the abuse of power, decreasing market competition, and misallocating resources. Corruption infects every business sector, including sport.

Maennig (2005) categorized the two types of sport corruption as "management corruption" and "competition corruption." Management corruption are decisions made by sporting officials away from the sporting arena (Maennig, 2005), and competition corruption are attempts to deliberately distort the outcome of a sporting contest (Gorse, 2014). However, corruption related to global sporting competitions is not limited to the actions of the governing body or the event itself (Berg \& Rojas, 2015). In fact, the United Nations Global Compact considers bribery connected to a sport sponsorship to be sport corruption as well.

However, the United Nations does not possess any legal authority over corruption. Individual nations define and criminalize corruption differently. There are some commonalities with many of these different laws. Generally, the laws typically make it illegal to bribe governmental officials in order to receive preferential treatment. This is known as active bribery. Passive bribery is the asking for a bribe and is illegal in some countries but not every single one. The differences in the laws make compliance difficult for multi-national companies, and especially for companies entering a new country for the first time. For instance, a company may reside in a jurisdiction where bribery is illegal but conduct business in a culture where corrupt behaviors like bribery and kick-backs are expected.

In the business context, there are transactional bribes and outright purchase. A transactional bribe is a payment that is routinely and impersonally made to a public official to secure or accelerate the performance of his official function. This type of bribe is commonly known as a grease payment. An outright purchase is a payment made in order to secure the favor of a foreign employee who remains in place in an organization to which he appears to pay full loyalty while actually favoring the briber's interest. 
While paying bribes (active bribery) is against the law for US and most European firms, it may be an accepted marketing activity for its competitors (Scott, Gilliard \& Scott, 2002). In fact, Scott, Gilliard \& Scott (2002) cites the National Export Strategy Report (1996) estimating that companies who are willing to bribe foreign officials win $80 \%$ of all business contract decisions. Further, the companies that bribe are more likely have home countries where bribery is either legal, or, accepted as an expected business practice (Scott, Gilliard \& Scott, 2002). Even though the global economy is beginning to include companies from these bribery-friendly countries, their behavior is not changing. In fact, the increased competition from companies from briberyfriendly countries, as well as, business competition within these bribery-friendly markets may actually escalate the incentive for typically compliant companies to match the illegal behavior.

Global sporting mega-events, such as the FIFA World Cup and The Olympic Games are being hosted in countries that possess a bribery-friendly business culture, such as Brazil, China and Russia. In this type of business culture, the local business community officials may expect benefits that would violate bribery law. This culture may create a dilemma for an international company engaged in sport sponsorship, especially through the activation of this sponsorship. The company must comply with appropriate bribery laws but may be solicited by local officials to violate those laws in order to conduct business. Sport sponsors will need to understand how the anti-bribery laws work, what the law covers, how to comply with the law and if the host location will increase legal scrutiny of the sponsorship activity.

\section{Sponsorship and hospitality}

Meenaghan (1983) defined sponsorship as the provision of assistance either financial or in-kind to activity by a commercial organization for the purpose of achieving commercial objectives. Sport sponsorship activation tactics may include hospitality. Hospitality is an experience that money cannot buy and often includes entertainment such as sport event tickets, travel, accommodations, food, etc. The marketing world has thrived on hospitality and its gifts to create a better relationship with an existing or potential customer in expectation of future business (Feast, 2011).

Hospitality is a vital sport sponsorship component and the legal scrutiny for bribery activity related to this sales action is increasing (Dodds, 2015). Sponsors, especially in a corporate hospitality context, measure success by the number and level of decision makers entertained, and what business was generated (Day, 2011). Program elements that are highly desired by visitors are those that are not commonly experienced (Dodds \& DeGaris, 2011). Tickets to a mega-event are highly desired. Thus providing a VIP experience with tickets to a sporting event creates sought-after corporate hospitality program, which can lead to a stronger relationship with the client.

\section{Sponsorship corruption}

Sponsors face many corruption-related risks (United Nations Global Compact, 2014, 11-12. The risks include active bribery (the promise, offering or giving, directly or indirectly, of an undue advantage to become a sponsor), and passive bribery (the promise, offering or giving, directly or indirectly, of an undue advantage by the sport entity to obtain sponsorship). A sport sponsorship 
needs to be aware of potential conflicts of interest with event officials, government officials and third party agents. Finally the misuse of a sport sponsorship to obtain an undue competitive advantage, and the misuse of sponsorship hospitality to obtain an undue advantage may lead to corrupt behavior.

\section{Legal discussion}

Many countries created specific anticorruption laws that regulate business conduct. These laws govern the bribery of their own officials as well as foreign officials of other sovereign nations.

In 1977, the United States' Foreign Corrupt Practices Act (FCPA) was the first law to criminalize bribery of foreign officials. The foreign official requirement includes most employees of a state-owned business commonly utilized in China. This act does not require the corrupt payment to be cash but it can be gifts, entertainment, drinks, meals, transportation, lodging and other items that are common to a sport sponsorship's hospitality program. Foreign companies listed on U.S. stock exchanges or conduct significant business within the United States must comply with the FCPA. If there is a violation of the FCPA, the corporation is subject to a $\$ 2$ million criminal fine and any individual (including corporate officers, directors or stockholders) who willfully violates the provisions of the law is subject to a $\$ 250,000$ fine and / or five year's imprisonment (Kaikati \& Label, 1980). However, a payment that is a reasonable and bona fide expenditure that is directly related to the promotion of a product or service is allowed.

United Kingdom's Bribery Act criminalizes any offer, promise or gift of any financial or other advantage or other advantage is given to a foreign public official to obtain or retain business. This law specifically bans hospitality given with the intention to induce a person to perform a function improperly. Initially, this provision caused concern for sponsors of the 2012 Summer Olympic Games in London. However, enforcement of The Bribery Act has allowed reasonable hospitality expenses (Harrington, 2012).

In 2013, Brazil passed its anticorruption law known as "The Clean Companies Act." The enactment of this law help prepare Brazil for its hosting of the 2014 FIFA World Cup and the 2016 Rio Summer Olympic Games (Correia, Bartley, \& Freitas, 2013). This law forbids bribes to both domestic and foreign officials as well as related third parties for the purpose of gaining an unjust advantage. While the law is not limited to the bribing of foreign officials, it does not require proof of corrupt intent (Correia, Bartley, \& Freitas, 2013). Violations of the law may result in fines up to $20 \%$ of the company's annual gross revenues (Correia, Bartley, \& Freitas, 2013 ) but no criminal penalties. A company may receive some leniency on its sanctions if it voluntarily discloses the violations and cooperates with any investigation. (Latham \& Watkins, 2014).

\section{Illustrative cases}

In 2013, Weatherford International faced bribery charges from improper hospitality expenses associated with the 2006 FIFA World Cup in Germany. Weatherford provided match tickets, travel and entertainment to officials of a state-owned company in Algeria to ensure the renewal 
of oil contracts (SEC.gov, 2013). Although Weatherford is a Swiss company and the activity was conducted in Germany, the FCPA applied because Weatherford had substantial operations in the United States, including a headquarters in Houston, Texas (SEC.gov, 2013). Weatherford was found to lack the internal controls needed to prevent corrupt behavior. Although Weatherford paid almost $\$ 115$ million on investigating the allegations (FCPAblog,com, 2013), it was fined more than $\$ 120$ million including $\$ 1.875$ million for its lack of cooperation with the government (SEC.gov, 2013).

As part of its 2008 Summer Olympic Games in Beijing, China, BHP Billiton Ltd. The Australian mining company whose stock trades on the New York Stock Exchange supplied the gold, silver and bronze metal for the awards (Paul \& Hornsby, 2013). To activate this sponsorship, BHP Billiton provided hospitality for guests of China state-owned steel-making firms. The hospitality included event tickets, luxury hotel accommodations, and sightseeing worth up to $\$ 16,000$ per trip (SEC.gov, 2015). Although BHP Billiton had internal controls, it did not go far enough to prevent bribery violations (Dodds, 2015). Although the corporate procedures required the expenses to be reviewed, they were never examined by anyone outside the business unit. BHP Billiton also failed to train its employees on bribery risks and prevention (SEC.gov, 2015). BHP Billiton self-reported these FCPA violations and cooperated with the government's investigation, which led to a settlement consisting of a \$25 million fine (Dodds, 2015).

Sport sponsorship bribery activity may include infrastructure projects (Dodds \& Palmero, 201X). A leading international engineering and services group, Bilfinger SE, faced allegations of corruption from its sponsorship of the 2014 FIFA World Cup in Brazil. The German company is accused of paying bribes related to orders to equip security command centers at twelve host cities (dw.com, 2015). The allegations focus on suspected payments to governmental officials who hired Bilfinger to supply 1,200 security monitors and software to run the police, fire and emergency services (dw.com, 2015). Bilfinger became the first international company to disclose to the Brazilian government that it may have paid bribes in order to seek leniency (Stauffer, 2015).

\section{Identify risks}

Sponsors using hospitality in connection with sporting events, especially in markets where business corruption is common, should be aware of potential risks (Rogers, 2014). Every sponsor needs to scrutinize the situation very closely in order to make certain no corrupt behavior is committed. Some red flags that may indicate corruptive behavior includes:

1. Using a third party agent, representative or distributor that has previously violated a local law, even if that law is not bribery. This act may indicate that the agent might create criminal liability for the sponsor via the agent's behavior.

2. An unusual request for additional money such as a bonus or one-time payment. This payment may indicate a bribe, grease payment, or kickback to an official. The initial budget should cover all anticipated expenses. If there is a new expense, then the sponsor should investigate this expense with the vender or governmental agency directly.

3. An agent asking for additional money above the contracted amount. 
4. Public or government officials (or family) that are stakeholders in the hosted organization. This might be commonplace in markets with state-owned companies (China), or developing nations with a bribery-friendly business culture. The bribery may include payments or benefits to close family members of the governmental official.

5. Additional travel is requested (new location, additional persons, more luxurious accommodations, etc.) by the hospitality guests or third party agent.

6. Non-specific charges (training, appearance fee, publications, etc.) should be investigated directly. Bribery activity may be hidden within what appears to be a legitimate appearing expense.

\section{Recommendations}

Sport sponsorship hospitality may be difficult to distinguish from a bribe. Both activities might include event tickets, transportation, lodging, food and entertainment. A sport sponsor needs to take steps in order to comply with bribery laws, especially in markets with bribery-friendly business cultures.

Every organization that engages in sport sponsorship should create a separate corporate compliance department overseeing all international marketing activity. The department must write a clear policy against the corruption of foreign officials. This policy needs to be endorsed by the highest levels of the organization (Day, 2012) with a clear commitment showing senior management obeying its procedures. The sport sponsor needs to establish a comprehensive training program to review potential corrupt situations and red flags. This step reinforces proper behavior. Finally, an internal enforcement department should review all hospitality contracts and expenses. All payments need to reflect a reasonable and bona fide expenditure that is directly related to the promotion of a product or service. If potential violations are found, prompt disciplinary action needs to be taken (Kaeikati \& Label, 1980). This includes self-reporting the violations and cooperating with the government's investigation (Dodds, 2015). The Weatherford and BHP Billiton cases resulted in very different penalties that were due, in part, to the level of cooperation shown by the companies.

Organizations that manage international sporting events should research all applicable laws to ensure compliance by itself and its sponsors. Sporting events are being hosted by many developing nations. These markets may not regulate either active or passive bribery, or may not enforce any laws banning corrupt activity. Despite have over 40 nations agreeing to the terms of the international Organization for Economic Co-operation and Development [OECD] AntiBribery Convention agreement, Transparency International reports that only the United States, Germany, Great Britain and Switzerland actively enforce it (Rising, 2013). Conversely, half of these countries showed little to no enforcement for their laws (Rising, 2013). Much of the limited enforcement is attributed to a lack of resources dedicated to its investigation and prosecution (Rising, 2013),

A sponsor should take additional care when hosting officials at corporate hospitality events. The sponsor should not select the particular official who will participate in the event, the selection 
should be made by the other organization, or use a pre-determined, merit based criteria. The company should investigate the list of attendees for relatives of governmental officials.

Finally, when contracting with a third party agent, a corporation should ensure that all expenditures are transparent, clearly documented, and for the actual amount of any incurred expenses. This may prevent bribes that are hidden as legitimate expenses.

\section{Conclusion}

Anticorruption law criminalizes the bribery behavior but does not change the corrupt culture that may exist where a sporting event is held (Dodds, 2016). Sport sponsors need to understand all applicable laws and create protocols that establishes compliance. Sport sponsorships can be an effective tool to achieve commercial objectives, however, any anticorruptive actions may lead to a significant fine, criminal sanctions, and negative publicity.

\section{References}

Berg, N., and Rojas, G. D. (2015, March 26). Shooting for effective anti-corruption compliance: A look at recent developments in Brazil. Ropes \& Gray. Retrieved from: https://www.ropesgray.com/newsroom/alerts/2015/March/Shooting-for-Effective-AntiCorruption-Compliance-A-Look-at-Recent-Developments-in-Brazil.aspx

Correia, M., Bartley, M., and Freitas, R. (2013, Sept 24). A comparison of the new Brazilian anticorruption law, the FCPA and the UK bribery act. Association of Corporate Counsel. Retrieved from: http://www.acc.com/legalresources/quickcounsel/cnbalfuba.cfm?makepdf=1

Day, H. (2011). How to avoid sponsorship and hospitality becoming forms of bribery. Journal of Sponsorship, 4(2), 100-104.

Dodds, M. \& DeGaris, L. (2011). Using Mobile Marketing to Engage NASCAR Fans and Increase Sales. Sports Management International Journal Choregia, 7(1), 63-75.

Dodds, M., \& Palmero, M. (201X). What can Bilfinger teach Olympic sponsors? (submitted to Sports Management International Journal Choregia)

Dodds, M. (2016). Revisiting the Salt Lake City Olympic scandal: Would the outcome be different today? Sports Management International Journal Choregia, 12(1), 1-14.

Dodds, M. (2015). Foreign Corrupt Practices Act cases impact sport marketing strategies. Sport Marketing Quarterly, 24(4), 258-260.

dw.com (2015, March 22). Germany's Bilfinger announces probe into possible Brazil 2014 World Cup bribes. Reuters. Retrieved from: http://www.dw.com/en/germanys-bilfingerannounces-probe-into-possible-brazil-2014-world-cup-bribes/a-18333176

FCPAblog.com (2013, November 26). Weatherford pays \$152.6 million for FCPA violations, $\$ 100$ million for trade sanctions. Retrieved from: 
http://www.fcpablog.com/blog/2013/11/26/weatherford-pays-1526-million-for-fcpa-violations100-millio.html

Feast, S. (2011). There's no such thing as a free lunch. Credit Management, May2011, 4.

Gorse, S. (2014). Corruption in international sport: Implications for sponsorship management. Unpublished doctoral thesis, Coventry University, UK.

Harrington, A. (2012). The Bribery Act- one year on. Financial Management, 41(3), 50-53.

Joutsen, M. \& Keränen, J. (2009). Corruption and the prevention of corruption in Finland. Ministry of Justice: Finland.

Kaikati, J. \& Label, W. (1980). American bribery legislation: An obstacle to international marketing. Journal of Marketing, 44(4), 38-43.

Latham \& Watkins, (2014, January 6). Brazilian anti-corruption law: 7 implications and challenges for companies doing business in Brazil. Retrieved from: https://www.lw.com/.../lwbrazil-anti-corruption-law

Maennig, W. (2005). Corruption in international sports and sport management: Forms, tendencies, extent and countermeasures. European Sport Management Quarterly, 5(2), 187-225.

Meenaghan, J.A. (1983). Commercial sponsorship. European Journal of Marketing, 17(7), 5-73.

Paul, S. and Hornby, L. (2013, March 13). BHP Billiton faces corruption probe over Beijing Olympics. Reuters. Retrieved from: http://www.reuters.com/article/2013/03/13/us-bhpinvestigation-olympics-idUSBRE92C00G20130313

Rising, D. (2013). Wathdog (sic): Anti-bribery rules not being enforced. Associated Press. Retrieved October 8, 2013, from http://abcnews.go.com/International/wireStory/wathdog-antibribery-rules-enforced-20502034

Rogers, HL. (2014, May 30). Corporate hospitality is major risk area during World Cup. Law360. Retrieved from: http://www.law360.com/articles/542886/corporate-hospitality-ismajor-risk-area-during-world-cup

Scott, J., Gilliard, D. \& Scott, R. (2002). Eliminating bribery as a transactional marketing strategy, International Journal of Commerce \& Management, 12(1), 1-17.

SEC.gov (2013, November 26). SEC charges Weatherford International with FCPA violations. Retrieved from:

http://www.sec.gov/News/PressRelease/Detail/PressRelease/1370540415694\#.VRAtTeHpx8t

SEC.gov (2015, May 20). SEC charges BHP Billiton with violating FCPA at Olympic Games. Retrieved from: http://www.sec.gov/news/pressrelease/2015-93.html

Stauffer, C. (2015, May 7). Brazil comptroller says Germany's Bilfinger seeking leniency deal. Reuters. Retrieved from: http://www.reuters.com/article/2015/05/07/brazil-corruption-bilfingeridUSLIN0XY1XY20150507 
Transparency International (2016). What is corruption? Retrieved from $\mathrm{http}: / /$ www.transparency.org/what-is-corruption/\#define

United Nations Global Compact. (2014). Fighting corruption in sport sponsorship and hospitality: A practical guide for companies. Retrieved from:

https://www.unglobalcompact.org/docs/issues_doc/Anti-

Corruption/SportsSponsorshipHospitalityGuide.pdf 